Allogeneic PG, as opposed to autologous PG, is preferred because it can be obtained from young and healthy donors, providing a high dose of functioning platelets with minimal risk of bacterial contamination.

This is the first published report, to our knowledge, of treating DSWI by means of injection of allogenic PG. Considering the disappointing results seen with the surgical treatment of DSWI, especially for high-risk patients, nonsurgical therapy consisting of a combination of biologic (PG) and mechanical (VAC) methods might be advantageous as a simple, inexpensive, and safer therapy.

\section{References}

1. Yuen JC, Zhou AT, Serafin D, Georgiade GS. Long-term sequelae following median sternotomy wound infection and flap reconstruction. Ann Plast Surg. 1995;35:585-9.

2. Orenstein A, Kachel E, Zuloff-Shani A, Paz Y, Sarig O, Haik J, et al. Treatment of deep sternal wound infection post open heart surgery by application of activated macrophages suspension. Wound Repair Regen. 2005;13:237-42.

3. Sjögren J, Mokhtari A, Gustafsson R, Malmsjö M, Nilsson J, Ingemansson R. Vacuum-assisted closure therapy for deep sternal wound infections: the impact of learning curve on survival and predictors for late mortality. Int Wound J. 2008;5:216-23.

4. Hom DB, Linzie BM, Huang TC. The healing effects of autologous platelet gel on acute human skin wounds. Arch Facial Plast Surg. 2007;9:174-83.

5. Trowbridge CC, Stammers AH, Woods E, Yen BR, Klayman M, Gilbert C. Use of platelet gel and its effects on infection in cardiac surgery. J Extra Corpor Technol. $2005 ; 37: 381-6$

\title{
Right ventricular reverse remodeling is possible despite twenty-one years of absent tricuspid valve and severe right ventricular failure
}

\author{
Ramohan Marla, MD, Judy Fox, RNP, Raymond Q. Migrino, MD, Lee Biblo, MD, and R. Eric Lilly, MD, \\ Milwaukee, Wis
}

Recovery of impaired right ventricular (RV) function after tricuspid valve (TV) replacement for long-standing chronic tricuspid regurgitation is not predictable. Poor preoperative $\mathrm{RV}$ function and enlarged RV dimensions are not always reversible after TV replacement. We report a case of complete return to normal of RV dimensions and function after TV replacement for severe tricuspid regurgitation of 21 years' duration.

\section{CLINICAL SUMMARY}

A 48-year-old woman with history of TV excision at another institution 21 years previously for staphylococcal endocarditis was admitted with class IV heart failure. During the ensuing 5 years, she had progressively worsening functional status and finally was seen with overt right heart failure in atrial flutter with ascites and pleural effusions. A transthoracic echocardiogram revealed a small left ventricle with leftward displacement of the interventricular septum, severely dilated RV with diminished RV systolic function, and absent TV (Figure 1, $A-C$ ). Right heart catheterization revealed Fick-derived cardiac index of $1.57 \mathrm{~L} /$

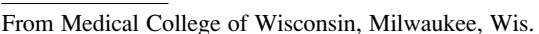

Disclosures: None.

Received for publication April 23, 2009; accepted for publication May 17, 2009; available ahead of print July 30, 2009

Address for reprints: R. Eric Lilly, MD, Medical College of Wisconsin, Cardiothoracic Surgery, Froedtert East, Suite 5700, 9200 W Wisconsin Ave, Milwaukee, WI 53226 (E-mail: relilly@mcw.edu).

J Thorac Cardiovasc Surg 2010;139:e120-2

$0022-5223 / \$ 36.00$

Copyright (c) 2010 by The American Association for Thoracic Surgery doi:10.1016/j.jtcvs.2009.05.018 $\left(\mathrm{min} / \mathrm{m}^{2}\right)$, pulmonary vascular resistance of 3.86 Wood units, and pulmonary capillary wedge pressure of $19 \mathrm{~mm}$ $\mathrm{Hg}$. No coronary artery disease was noted on left heart catheterization.

A 33-mm St Jude Biocor porcine valve (St Jude Medical, Inc, St Paul, Minn) was sutured into the tricuspid position by way of a resternotomy. Midrange inotropic support without nitric oxide was required for successful weaning from cardiopulmonary bypass. Cardiac index gradually improved, and the patient was discharged home on postoperative day 14 in normal sinus rhythm. A transthoracic echocardiogram obtained 6 months after surgery demonstrated RV reverse remodeling with improved left ventricular geometry (Figure $1, D-F$ ) and normal RV dimensions, as defined by the American Society of Echocardiography ${ }^{1}$ (Table 1). At 6 months, the patient had no signs of heart failure and nearly normal exercise tolerance.

TABLE 1. Right ventricular chamber dimensions preoperatively and at 6 postoperative months of follow-up

\begin{tabular}{lccc}
\hline \multicolumn{1}{c}{ Measurement } & $\begin{array}{c}\text { Reference range } \\
(\mathbf{c m})\end{array}$ & $\begin{array}{c}\text { Preoperative } \\
(\mathbf{c m})\end{array}$ & $\begin{array}{c}\text { Follow-up } \\
(\mathbf{c m})\end{array}$ \\
\hline $\begin{array}{l}\text { Right ventricular } \\
\text { basal diameter }\end{array}$ & $2-2.8$ & 5 & 2.8 \\
$\begin{array}{l}\text { Mid right } \\
\quad \text { ventricular diameter }\end{array}$ & $2.7-3.3$ & 3.5 & 3.2 \\
$\begin{array}{l}\text { Base to apex length } \\
\text { Above aortic valve }\end{array}$ & $7.1-7.9$ & 7.5 & 7.2 \\
$\begin{array}{l}\text { Above pulmonic valve } \\
\text { Mench }\end{array}$ & $1.7-2.3$ & 5.6 & 4.4 \\
\hline
\end{tabular}

Measurements and reference ranges were obtained according to standard American Society of Echocardiography recommendation. ${ }^{1}$ 

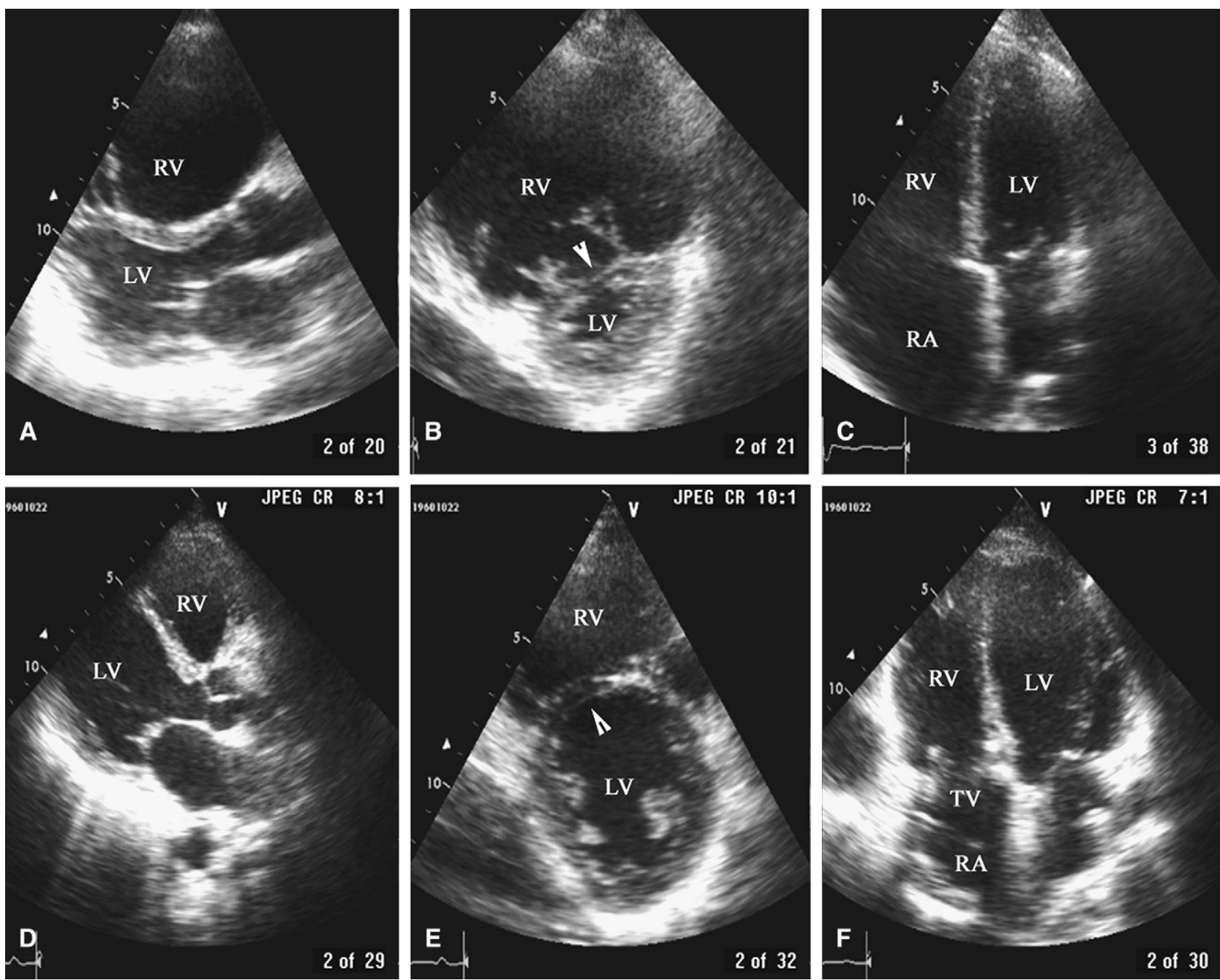

FIGURE 1. A through $\mathrm{C}$, Preoperative transthoracic echocardiography views demonstrating dilated right ventricle $(R V)$ with small left ventricle $(L V)$ and flattened interventricular septum (arrowhead). D through F, Six-month postoperative echocardiography in parasternal long axis (D), parasternal short axis (E), and apical 4-chamber $(\mathrm{F})$ views showing bioprosthetic tricuspid valve $(T V)$. There was dramatic reduction in right ventricular and right atrial $(R A)$ sizes, with reverse remodeling of right ventricle and recovery of left ventricular geometry.

\section{DISCUSSION}

Longstanding tricuspid insufficiency induces severe RV dilatation and dysfunction. Most commonly, severe tricuspid insufficiency occurs in response to increased pulmonary vascular resistance or left-sided disease. Consequently, most tricuspid procedures are performed in conjunction with left-sided valvular procedures, and the natural history of recovery of RV function after coincidental TV repair is well described. ${ }^{2}$ Reported mortalities for TV operations range from $13 \%$ to $20 \%{ }^{3,4}$ The extremely high mortalities reported for these patients are often attributed to comorbid conditions, such as multivalvular heart disease or endocarditis. Specific factors predicting increased mortality risk include elevated preoperative pulmonary vascular resistance, left ventricular disease, RV dysfunction, and low cardiac output. ${ }^{5}$
Operations for isolated TV disease are uncommon, although isolated TV procedures are more common in younger patients. Predictors of successful RV reverse remodeling and good clinical outcomes are not well described.

Before the operation, our patient demonstrated signs of left ventricular dysfunction, with elevated pulmonary capillary wedge pressure and diminished cardiac index in the presence of severe RV dysfunction. These factors would certainly portend a high perioperative mortality risk. Our patient, however, did remarkably well. A large prosthesis, relatively low pulmonary vascular resistance, and absence of true left-sided heart pathology all likely contributed to this successful outcome. Reverse remodeling to normal $\mathrm{RV}$ dimensions, recovery of RV function, and absence of heart failure symptoms surprisingly had all occurred by 6 postoperative months, despite 21 years of absent TV. This 
case supports an aggressive surgical approach for these often critically ill patients.

\footnotetext{
References

1. Lang RM, Bierig M, Devereux RB, Flachskampf FA, Foster E, Pellikka PA, et al. Recommendations for chamber quantification: a report from the American Society of Echocardiography's Guidelines and Standards Committee and the Chamber Quantification Writing Group, developed in conjunction with the European Association of Echocardiography, a branch of the European Society of Cardiology. $J$ Am Soc Echocardiogr. 2005;18:1440-63.
}

2. Hayashi J, Okazaki H, Nakazawa S, Watanabe H, Miyamura H, Eguchi S. Right ventricular systolic performance before and after surgery for tricuspid regurgitation associated with mitral stenosis. Jpn Circ J. 1996;60:96-101.

3. Filsoufi F, Anyanwu C, Salzberg SP, Frankel T, Cohn LH, Adams DH. Long-term outcomes of tricuspid valve replacement in the current era. Ann Thorac Surg. 2005; 80:845-50.

4. Moraca RJ, Moon MR, Lawton JS, Guthrie TJ, Aubuchon KA, Moazami N, et al. Outcomes of tricuspid valve repair and replacement: a propensity analysis. Ann Thorac Surg. 2009;87:83-9.

5. Péterffy A, Jonasson R, Henze A. Hemodynamic changes after tricuspid valve surgery. A recatheterization study in forty-five patients. Scand J Thorac Cardiovasc Surg. 1981;15:161-70.

\title{
Overcoming challenges: The use of minimal extracorporeal circulation in Jehovah's Witnesses undergoing cardiac surgery
}

\author{
Anil John, FRCS, Mark Bennett, MD, FRCA, Clinton Lloyd, FRCS (CTh), and Simon Allen, FRCS (CTh), \\ Plymouth, United Kingdom
}

Cardiac surgery in Jehovah's Witnesses often poses a challenge to the surgeon because these patients refuse transfusion of the primary components of blood (red cells, white cells, plasma, and platelets), although individual believers can decide for themselves to accept processed fractions of the primary components. Most cardiac surgeons around the world use standard cardiopulmonary bypass circuits for coronary artery bypass grafting in these patients. Minimal extracorporeal circulation (MECC) is a fully heparin-coated closed-loop cardiopulmonary bypass system. It excludes the blood-gas interface and has active venous drainage, a centrifugal pump, membrane oxygenator, and a priming volume of $800 \mathrm{~mL}$, reduced further to around $300 \mathrm{~mL}$ by the use of retrograde priming of the circuit.

\section{CLINICAL SUMMARY}

Between May 2007 and February 2009, 7 Jehovah Witness patients underwent cardiac surgery using this technique (coronary artery bypass grafting in 6 and aortic valve replacement in 1). There were 6 male patients and 1 female patient with an average age of 63 years. Comorbidites included hypertension, and 1 patient had poor left ventricular function (Table I).

\footnotetext{
From the Southwest Cardiothoracic Centre, Cardiothoracic Surgery, Derriford Hospital, Plymouth, United Kingdom.

Disclosures: None.

Received for publication July 12, 2009; revisions received Aug 26, 2009; accepted for publication Sept 16, 2009; available ahead of print Nov 20, 2009.

Address for reprints: Anil John, FRCS, Southwest Cardiothoracic Centre, Department of Cardiothoracic Surgery, Derriford Hospital, Plymouth PL6 8DH, United Kingdom (E-mail: ajohn234@hotmail.com).

J Thorac Cardiovasc Surg 2010;139:e122-3

$0022-5223 / \$ 36.00$

Copyright (c) 2010 by The American Association for Thoracic Surgery doi:10.1016/j.jtcvs.2009.09.024
}

Average preoperative hemoglobin level was $14 \pm 2.01$ $\mathrm{g} / \mathrm{dL}$; postoperative hemoglobin level $10.35 \pm 1.32 \mathrm{~g} / \mathrm{dL}$ and percentage drop of hemoglobin on day 1 was $25 \% \pm$ $9.04 \%$. Average bypass time was $53 \pm 8.57$ minutes.

\section{DISCUSSION}

Standard cardiopulmonary bypass circuits are associated with marked hemodilution in addition to initiation of the inflammatory response because of contact between blood and artificial surfaces on the lines and oxygenator and also at the

TABLE 1. Patient characteristics

\begin{tabular}{|c|c|c|c|c|c|c|c|}
\hline & \multicolumn{7}{|c|}{ Patient no. } \\
\hline & 1 & 2 & 3 & 4 & 5 & 6 & 7 \\
\hline Age $(y)$ & 65 & 71 & 71 & 50 & 64 & 50 & 72 \\
\hline Sex & $\mathrm{M}$ & M & $\mathrm{M}$ & M & $\mathrm{M}$ & $\mathrm{M}$ & $\mathrm{F}$ \\
\hline Hypertension & No & Yes & Yes & Yes & No & Yes & No \\
\hline LV function & Good & Good & Poor & Good & Good & Good & Good \\
\hline Surgery & CABG & $\mathrm{CABG}$ & $\mathrm{CABG}$ & CABG & $\mathrm{CABG}$ & $\mathrm{CABG}$ & AVR \\
\hline No. of grafts & 3 & 3 & 3 & 2 & 3 & 2 & None \\
\hline Preop Hb (g/dL) & 14.8 & 14 & 9.7 & 13.9 & 15.6 & 15.6 & 14.2 \\
\hline Crossclamp (min) & 30 & 34 & 36 & 23 & 27 & 25 & 37 \\
\hline Bypass time (min) & 51 & 62 & 57 & 36 & 60 & 52 & 52 \\
\hline Postop $\mathrm{Hb}(\mathrm{g} / \mathrm{dL})$ & 12.2 & 10.4 & 8.2 & 11.7 & 9.6 & 10.3 & 10.1 \\
\hline Drop in $\mathrm{Hb}(\%)$ & 18 & 26 & 15 & 16 & 38 & 34 & 28 \\
\hline Day $4 \mathrm{Hb}(\mathrm{g} / \mathrm{dL})$ & 14.2 & 11.4 & 8.7 & 11.4 & 11.3 & 11.2 & 10 \\
\hline Total blood loss (mL) & 540 & 470 & 865 & 380 & 420 & 310 & 440 \\
\hline Extubation time (h) & 2.5 & 4 & 2.5 & 2 & 2 & 2 & 3 \\
\hline ITU stay $(\mathrm{d})$ & 1 & 1 & 2 & 2 & 1 & 1 & 1 \\
\hline $\begin{array}{l}\text { Length of stay } \\
\text { in hospital (d) }\end{array}$ & 6 & 7 & 14 & 6 & 6 & 6 & 6 \\
\hline
\end{tabular}

